\title{
A NEW SPECIES OF THE FEATHER MITE GENUS CALCEALGES GAUD, 1952 (ACARIFORMES: TROUESSARTIIDAE) FROM THE LOWLAND TINY GREENBUL PHYLLASTREPHUS DEBILIS (PASSERIFORMES: PYCNONOTIDAE): MORPHOLOGICAL DESCRIPTIONS WITH DNA BARCODE DATA
}

\author{
Jacek Dabert ${ }^{1^{*}}$ and Marek Bąkowski ${ }^{2}$ \\ ${ }^{1}$ Department of Animal Morphology, Faculty of Biology, A. Mickiewicz University, \\ Poznań, Poland \\ ${ }^{2}$ Department of Systematic Zoology, Faculty of Biology, A. Mickiewicz University, \\ Poznań, Poland \\ *corresponding author; e-mail: dabert@amu.edu.pl
}

\begin{abstract}
A new species Calcealges bochkovisp. n. (Astigmata: Analgoidea) is described from the lowland tiny greenbul Phyllastrephus debilis (Sclater) from Mozambique. This species is close to C. gyroplax Gaud et Mouchet, 1957 described from African bulbuls. Both sexes of these species are very similar in general body shape: in particular, in the form of the epimerites and of the opisthosomal lobes, as well as in the shape of the dorsal shields. The main diagnostic feature of the new species is the striation of dorsal shields, especially pronounced on the prodorsum (in C. gyroplax, these shields lack striae and they are uniformly dotted). The standard morphological description is supplemented by the COI barcode data.
\end{abstract}

KEY WORDS: Calcealges, new taxa, morphology, mtDNA barcoding.

DOI: 10.21684/0132-8077-2019-27-2-165-174

\section{INTRODUCTION}

The genus Calcealges Gaud, 1952, together with 10 other genera, belongs to the feather mite family Trouessartiidae (Astigmata: Analgoidea), whose representatives occupy plumage of five avian orders: predominantly Passeriformes and, to a lesser extent, Caprimulgiformes, Coraciiformes, Cuculiformes and Piciformes. In the plumage of their hosts, trouessartiids inhabit vane surfaces of the primary and secondary wing remiges, as well as of the tail rectrices (Orwig 1968; Santana 1976). These mites are perfectly adapted to strong aerodynamic stresses that prevail in the aforementioned microhabitats and may inhabit both the dorsal and ventral surfaces of the feathers (Mironov 1987). Most representatives of the family are relatively big feather mites with elongated diamond-shaped bodies. Both sexes are strongly sclerotized, especially on the dorsal surface. In addition, the mites of both sexes are equipped with opisthosomal lobes (in males of most taxa, they are fused along the midline) and well-developed ambulacra on all leg tarsi.

Calcealges belongs to the trouessartiid genera, characterized by enlarged asymmetrical ambulacra III and IV in both sexes and by elongated legs III in males. Females of this genus, as well as of the closely related Neocalcealges Orwig, 1968, have their copulatory opening shifted from a typical terminal position to the medio-dorsal surface of the hysteronotum, where it is located on (or anterior to) the supranal concavity. As of now, 14 species of Calcealges have been described from passerine birds, and one-from Megapodiidae (obvious contamination). All of the above mentioned species have been collected from tropical and subtropical regions (Table 1) and they likely represent only a small portion of the real taxonomic diversity of this genus (Hernandes 2015).

Here, we describe a new species of Calcealges from a lowland tiny greenbul Phyllastrephus debilis (Sclater) (Pycnonotidae) collected in Mozambique. We compare this new species with the most phenotypically similar and probably closely related Calcealges gyroplax Gaud et Mouchet, 1957. The latter species inhabits the golden greenbul Calyptocichla serinus (Verreaux, J et Verreaux, E) - another African pycnonotid-as well as terrestrial brownbuls, Phyllastrephus terrestris (Swainson). This article is the first instance of a Calcealges species morphological description being supplemented by a mtDNA barcode sequence (COI).

\section{MATERIALS AND METHODS}

The material originated from a single specimen of Phyllastrephus debilis trapped in Mozambique by Zak Pohlen (Wildlife Conservation Society, USA) in 2017. Feather mites were collected in the field by carefully extracting $2-3$ secondaries from wings and storing them in vials containing $70 \%$ 
ethanol. After the examination, the birds were released back to the wild. Because all the mite individuals from the sample were subjected to DNA isolation, we applied a non-destructive method of extraction (Dabert et al. 2008). After this procedure, mite exoskeletons were mounted on slides in a Faure medium.

The morphological description of the new species follows the recent standards for trouessartiid species (Hernandes 2015; Mironov and Palma 2016; Mironov and Galloway 2019). The idiosomal and leg chaetotaxy follows Gaud and Atyeo (1996); nomenclature for coxal setation includes corrections proposed by Norton (1998). Drawings were made with a Leica DM5500 B microscope equipped with DIC illumination and a camera lucida. All measurements in the text and in the figures are in micrometres $(\mu \mathrm{m})$. The measurements were based on photos taken by a Leica DFC450 digital camera and calculated by the LAS v.4.6.1 software (2105, Leica Microsystems CMS GmbH). Measuring standards for particular structures are as follows: (i) body length is measured from the tips of the palps to the level of setae $h 3$ (after Orwig 1968); the length of idiosoma is measured from the anterior margin of a propodosoma to the posterior margin of opisthosomal lobes, including terminal membranes; the width of idiosoma is the greatest width, measured at the level of a sejugal furrow; (ii) hysterosoma's length is measured from the level of lateral incisions of a sejugal furrow to the posterior margin of opisthosomal lobes, including terminal membranes; hysteronotal shield's length is measured from the level of the anterior corners to the bases of setae $h 3$; (iii) the distance between idiosomal setae of the same pair is the distance between their bases; the distance between different pairs of setae is the distance between the their bases on either side of the body (the mean of two measures for each specimen). Photos were made by the aforementioned LAS Leica system using the Montage Multifocus option and modified in SHARPEN Projects software v1.19.02658 (2016, Franzis Verlag $\mathrm{GmbH}$ ).

The morphological description of the new species is supplemented with the barcode data of the mitochondrial cytochrome $\mathrm{c}$ oxidase subunit I gene 661 bps fragment (COI). The sequencing protocol follows Mironov et al. (2012). Due to the insufficient number of comparative DNA sequences for Calcealges, we have not conducted a formal species delimitation procedure based on the barcode data.
The only COI barcode sequences, available in the GenBank, originate from two unidentified Calcealges species collected in the USA (KU203091) from Regulus satrapa (Lichtenstein) (Passeriformes: Regulidae) and in Canada (MG409226, MG412689, MG410916, MG4127196) from Junco hyemalis (L.) (Passeriformes: Passerellidae, host data after Heather Proctor, University of Alberta, Canada).

Bird classification and scientific names are taken from Gill and Donsker (2019).

\section{SYSTEMATICS}

\section{Family Trouessartiidae Gaud, 1957 Genus Calcealges Gaud, 1952}

\section{Calcealges bochkovi sp. $\mathrm{n}$.}

(Figs. 1-5)

Type material. Male holotype, 4 male, 6 female paratypes (AMU 01762) from Phyllastrephus debilis (Sclater, 1899), Mozambique, Sofala Province, Cheringoma, Locality near Codzo (Khodzue) Gorge, $18^{\circ} 33^{\prime} 50.4^{\prime \prime} \mathrm{S}, 34^{\circ} 52^{\prime} 20^{\prime \prime} \mathrm{E}$, elevation-216 m, 20 April 2017, bird det. Z. Pohlen, mites leg. M. Bąkowski.

Description. Male (holotype, ranges for 4 paratypes in parentheses, Figs. 1, 3, 4A). Body length 409 (397-409); idiosoma, length $\times$ width, $374(362-399) \times 216(191-215)$; hysterosoma length 228 (219-254). Prodorsal shield nearly triangular in form, with posterior margin slightly concave and posterior corners acute, a pair of antero-lateral sclerotized parallel ridges present, surface with distinct transverse striation in posterior part and more oblique at lateral margins, length along midline 120 (219-127), width at posterior margin 148 (147-157) (Fig. 1A). External vertical setae $v e$ represented by microsetae in rudimentary alveoli situated at lateral margins of prodorsal shield. Internal vertical seta $v i$ and internal scapular setae $s i$ thin filiform, 22 (20-25) and 29 (22-31) long, respectively; setae $s i$ separated by 61 (53-61). External scapular setae se 165 (150-168) long, separated by 91 (89-98), set on striated tegument near lateral margins of the shield. Scapular shields extending to ventral surface, not fused to epimerites II. Humeral shields with waved dorsal margin and longitudinally ribbed ventral surface anterior to setae $c p$. Setae $c 2$ set on antero-medial angle of humeral shields, thick, narrowly lanceolate, 51 (47-52). Setae $c 3$ lanceolate with bidentate apex 


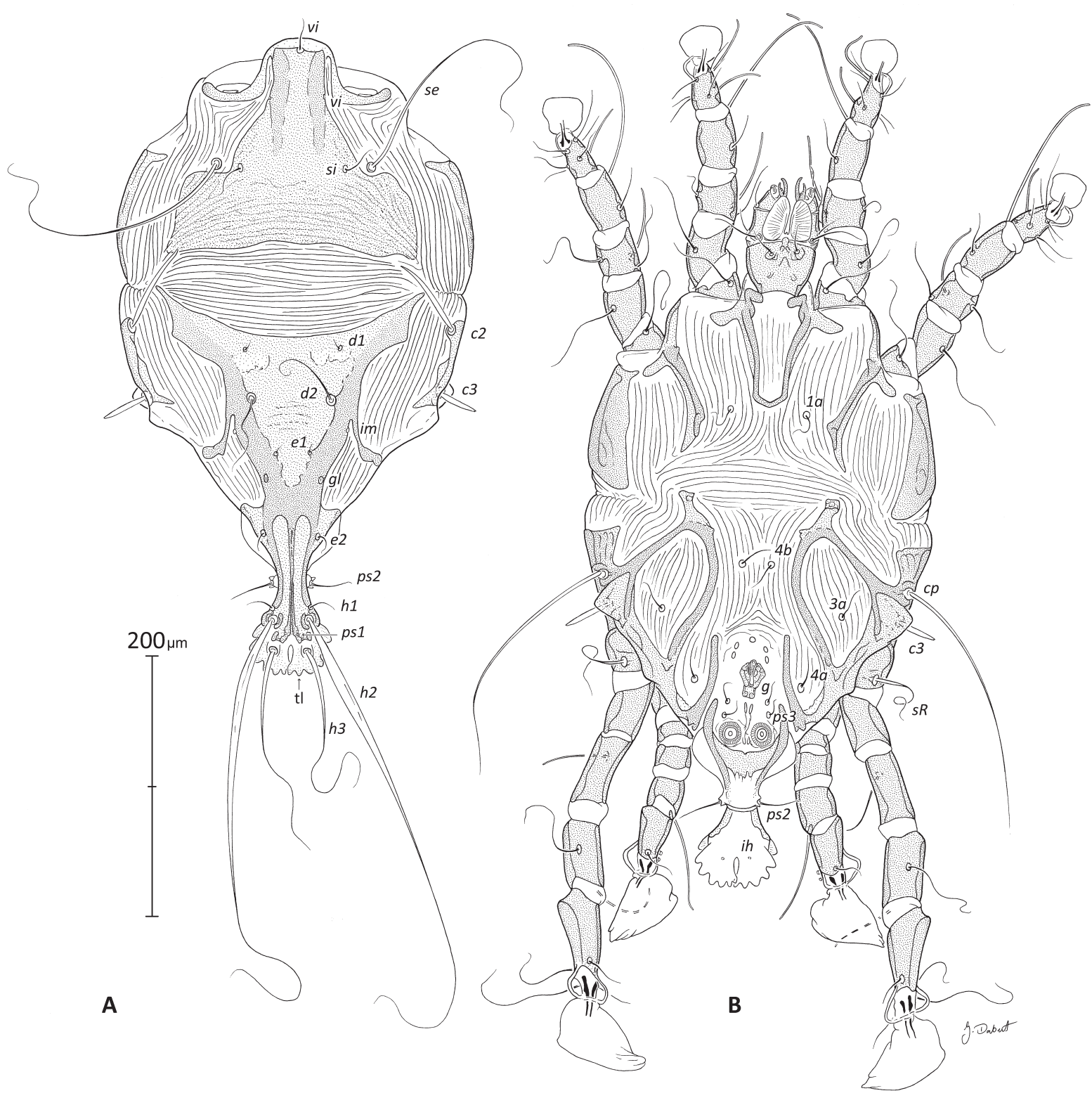

Fig. 1. Calcealges bochkovi sp.n., male. A-dorsal view, B-ventral view.

(sometimes indistinct because of aspect of this seta), 25 (26-30). Hysteronotal shield shaped as inverted triangle with concave anterior margin, length 211 (208-216), maximum width at anterior angles 165 (152-175); lateral margins with darkly sclerotized bands; surface uniformly dotted with sparse transverse striation in central part; lobar region with two parallel longitudinal areas of lighter sclerotization. Posterior part of opisthosoma spatuliform with a pair of terminal lamellae with 5-6 denticles each; length of lamellae from bases of setae $h 3$ to tip of lamellae 16 (15-18). Supranal concavity rudimentary, slit-like, set at the level of setae $e 2$. Setae $d l$ on hysteronotal shield near its anterior margin; setae $d 2$ filiform, 65 (63-80) long, exceeding distance between their bases. Setae $f 2$ absent. Setae $p s 1$ represented by microsetae. Distances between dorsal idiosomal setae and pores: $c 2: d 282$ (77-81), d1:d1 56 (48-56), d2:d2 49 (46-52), el:el 20(16-18), el:e2 51 (50-52), e1:h2 100 (100-104), e2:h2 51 (49-52), el:gl 18 (16-18), gl:e2 36 (34-36).

Epimerites I fused as a $U$ slightly narrowed posteriorly (Fig. 1B). Rudimentary sclerites rEpIIa fused with anterior angles of coxal fields III. Coxal fields III closed, IV open. Epimerites IVa extending anteriorly to level of epiandrum. Sclerites of genital apparatus shaped as elongated pen- 


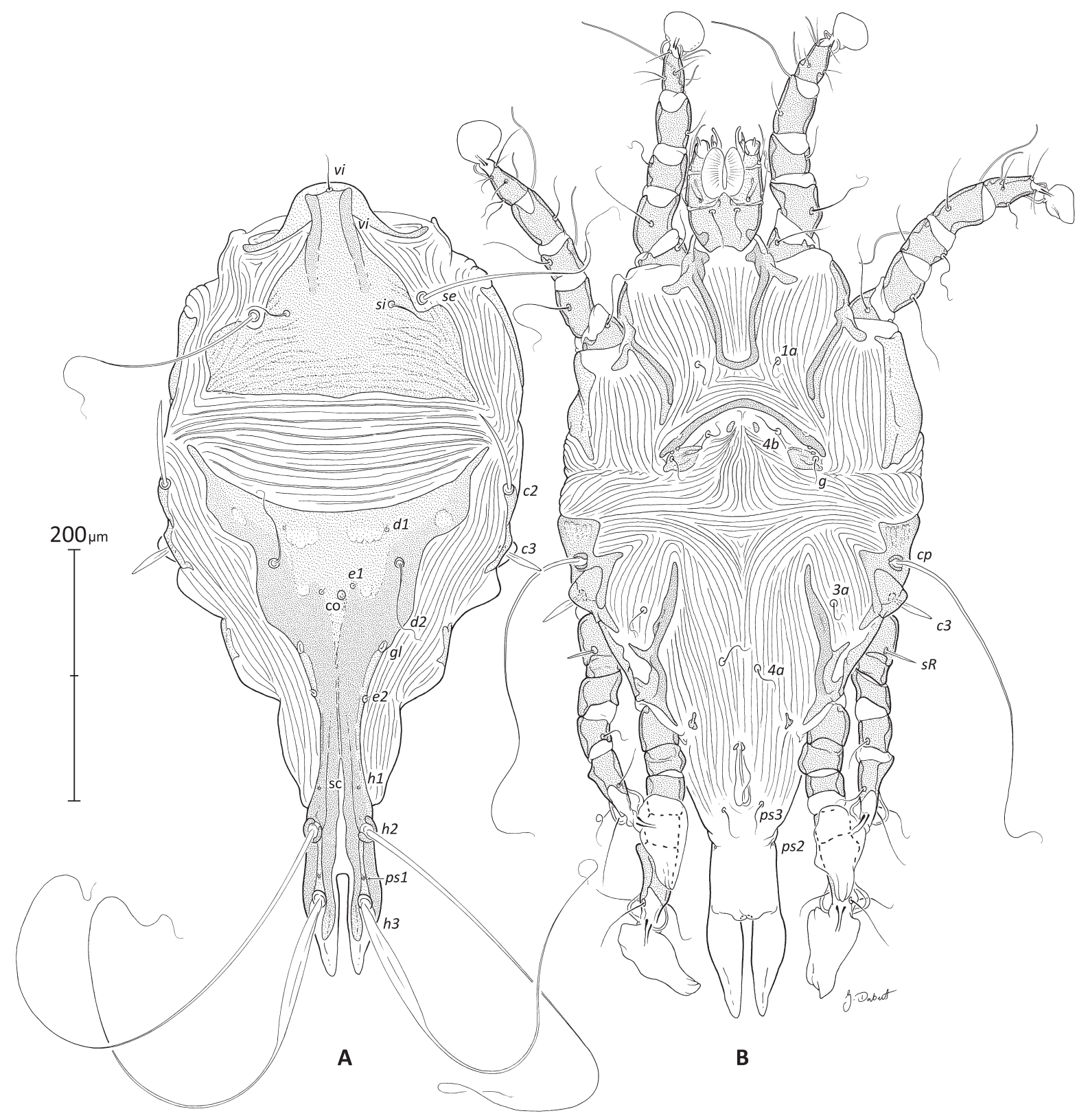

Fig. 2. Calcealges bochkovi sp.n., female. A-dorsal view, B — ventral view. Abbreviations: co-copulatory opening, sc-supranal concavity.

tagon, situated at level of trochanters III, length 24 (18-23), maximum width 16 (14-16). Aedeagus with ball-like apex (Fig. 4A), length 8 (9-11). Epiandrum shaped as a small spot-like sclerite situated anterior to level of first pair of genital papillae. Adanal apodemes well sclerotized, anterior tips attain the level of setae $g$; rounded lateral membranes present. Translobar apodeme wide. Anal suckers $12(10-12)$ in diameter, distance between their centres 18 (16-18). Setae $4 a$ situated slightly anterior to level of setae $g$. Distances be- tween ventral setae: $4 b: g 81$ (78-82), g:ps3 9 (810), ps3:ps2 50 (47-51).

Legs I and II of similar length; legs III much longer than anterior legs; legs IV shorter than anterior legs. Legs III with tarsus and distal part of tibia exceeding body terminus, legs IV with distal end of tarsus reaching body terminus. Tarsi III with distinct dorsobasal apophysis; this apophysis on tarsus IV is less developed. Setae $c G$ on genua I and II thickened basally with distal filiform part (Figs. 3A, B). Setae $s R$ on trochanters III filiform. 

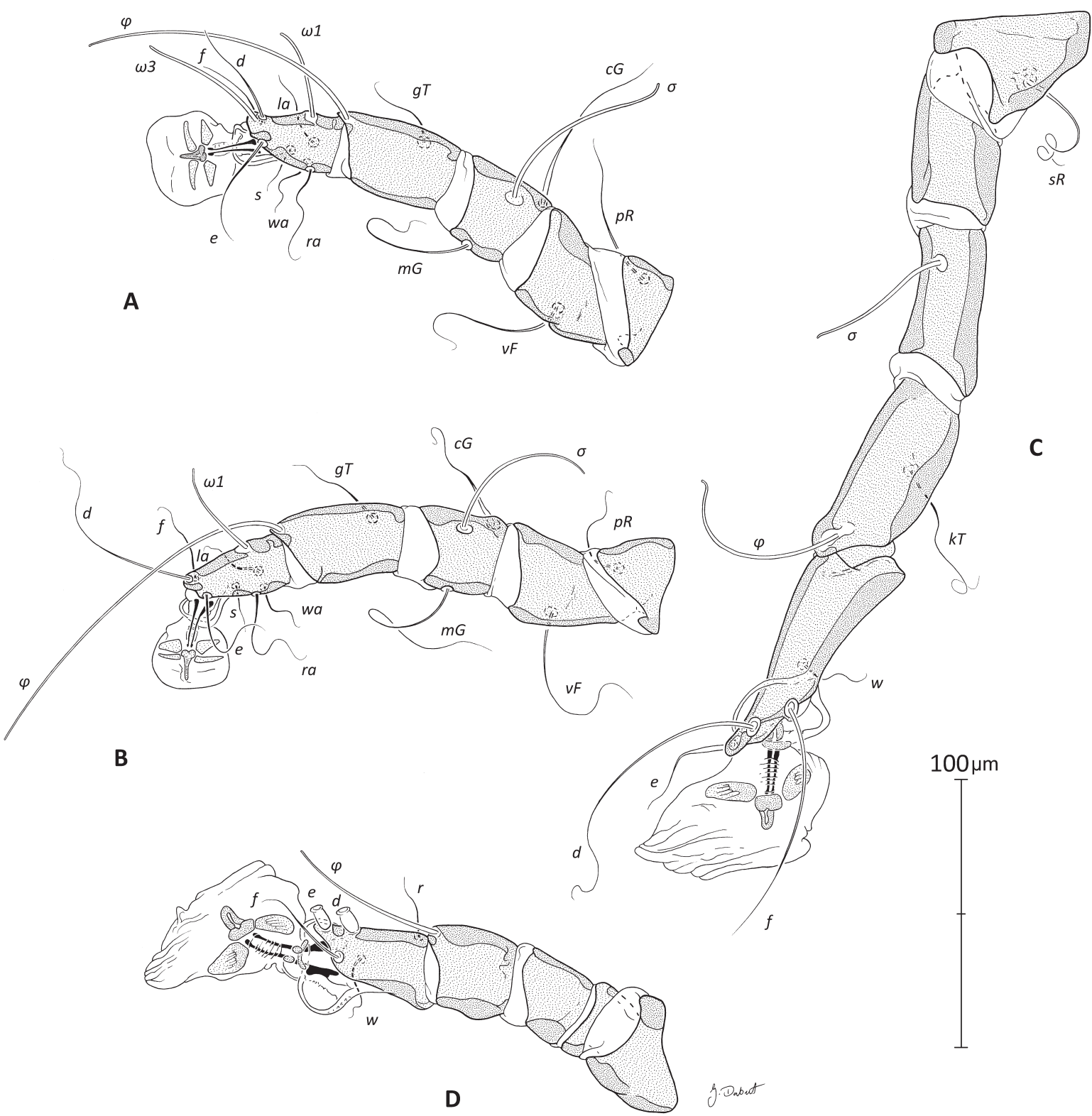

Fig. 3. Calcealges bochkovi sp.n., legs of male. A-leg I, B-leg II, C-leg III, D-leg IV.

Setae $d$ and $e$ on tarsi IV situated apically, both barrel-shaped with discoid cap (Fig. 3D). Length of solenidia: $\sigma$ I 73 (65-71), $\sigma$ II 54 (45-51), $\sigma$ III 38 (36-43), $\varphi$ I 85 (86-97), $\varphi$ II 101 (105-108), $\varphi$ III 57 (54-61), $\varphi$ IV 41 (37-43), $\omega 1$ I 27 (27-30), $\omega 3$ I 38 (33-38), $\omega 1$ II 27 (25-29).

Female (range for 6 paratypes, Figs. 2, 4B, 5). Body length 484-503; idiosoma, length $\times$ width, $482-499 \times 214-223$; length of hysterosoma 326338 . Prodorsal shield shaped and ornamented as in male, length 124-135, width 161-167. Vertical and scapular setae shaped and inserted as in males, $v i$ 20-27 long, si 23-30 long, separated by 65-68, se
167-179 long, separated by 104-107. Scapular and humeral shields shaped and ornamented as in males. Setae $c 2$ and $c 3$ shaped and inserted as in males, 48-53 and 28-32 long, respectively. Anterior half of hysteronotal shield shaped similarly to that in males but without medial striation, posterior part narrow and elongated, divided medially by narrow and deep incision (fused supranal concavity and terminal cleft) into two parallel parts covering opisthosomal lobes and reaching bases of setae $h 3$; length of shield 279-287, width 172-186. Posterior margin of opisthosoma with two parallelsided opisthosomal lobes with acute ends; terminal 

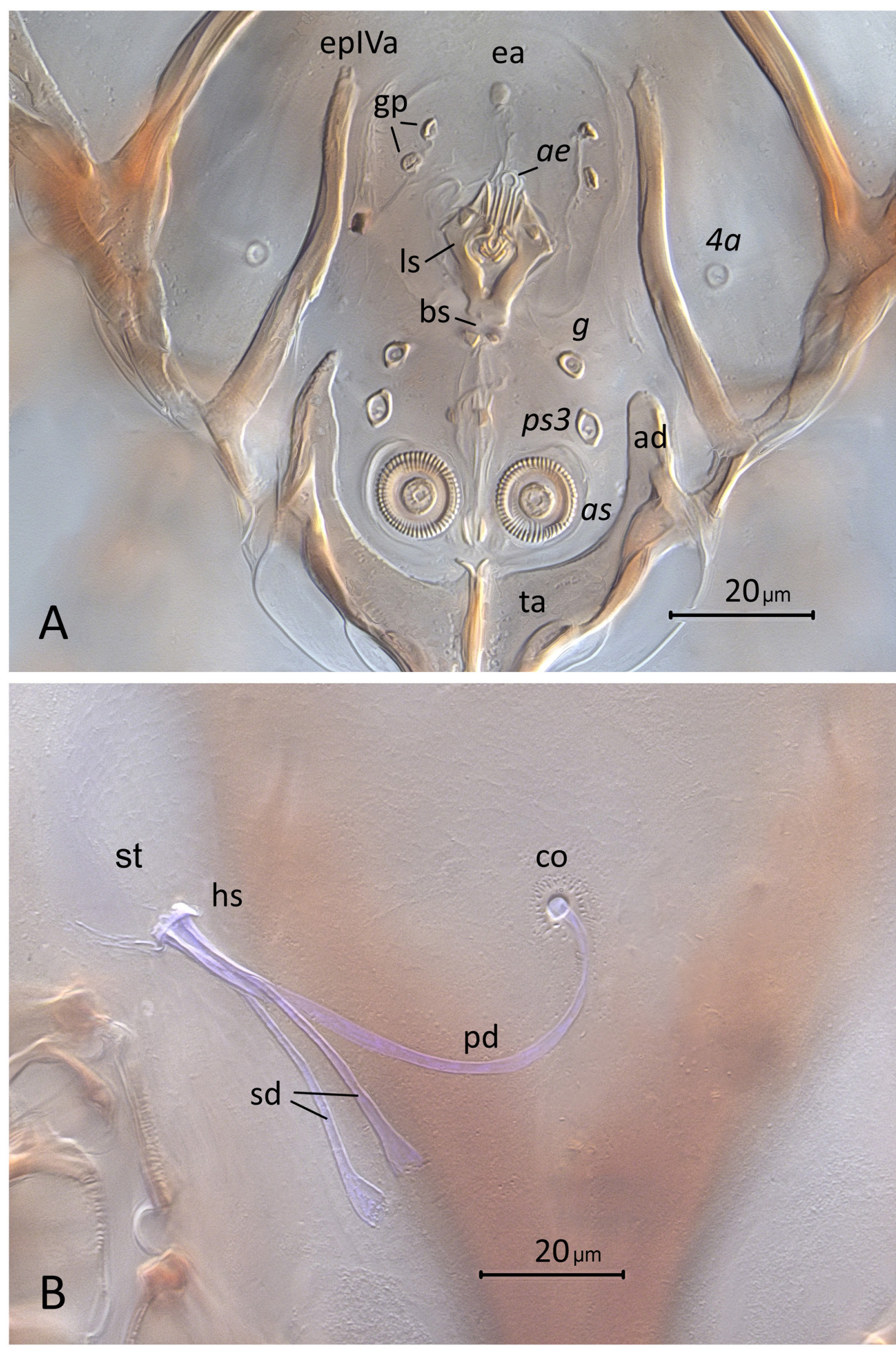

Fig. 4. Calcealges bochkovi sp.n., genital structures. A-male genito-anal region, B — spermatheca and spermaducts of female. Abbreviations: ad — adanal apodeme, ae — aedeagus, as - anal suckers, bs — basal sclerite, co-copulatory opening, ea - epiandrum, epIVa — epimerite IVa, gp — genital papillae, hs - head of spermatheca, ls - lateral sclerites, pd — primary spermaduct, sd—secondary spermaduct, st—spermatheca, ta—-translobar apodeme. 

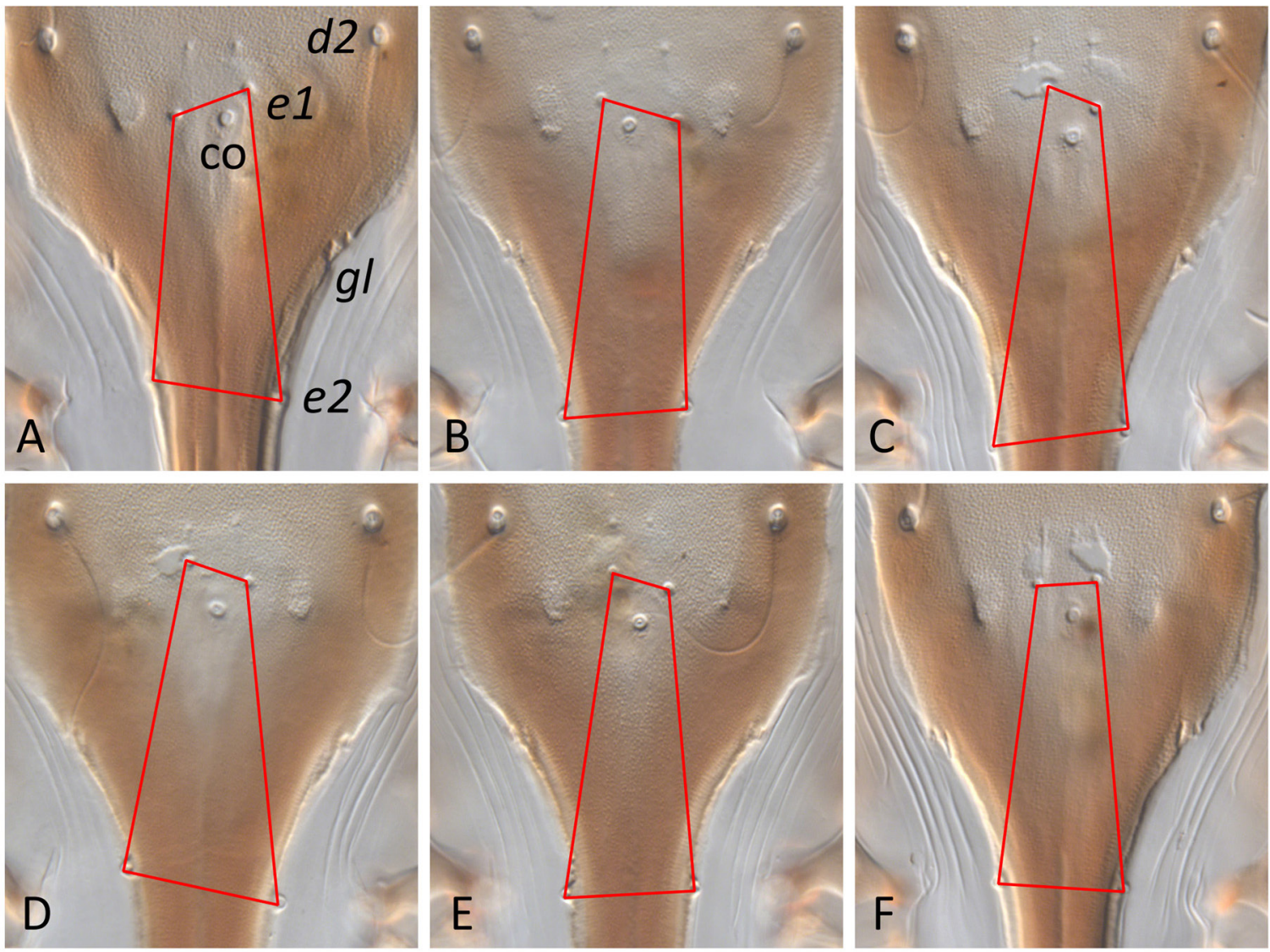

Fig. 5. Asymmetry in the distribution of the idiosomal setae e 1 and e 2 in five of the six female paratypes of Calcealges bochkovi sp.n. Only one female (F) has symmetrically arranged setae. Abbreviations: co - copulatory opening.

cleft length 58-61. Supranal concavity slit-like, with anterior end at $1 / 3$ distance $h 1-e 2$, open posteriorly into terminal cleft, length from anterior end of concavity to membranous margin of terminal cleft 74-79. Copulatory opening set dorsally, slightly posterior to setae el (see Remarks), 100104 from the anterior margin of the terminal cleft. Head of spermatheca with wide edentate collar, proximal part of primary spermaduct twice wider than remaining part, length of the primary spermaduct 75-81; secondary spermaducts with distal cup-like enlargements, 49-51 long (Fig. 4B). Setae $d 2$ reaching the bases of openings $g l$. Setae $e 1, e 2$, $h 1$, and $p s 1$ shaped as microsetae, setae $f 2$ absent. Setae $h 3$ set $44-48$ from hyaline lobar apices, shaped as macrosetae with distinctly expanded $1 / 3$ basal part. Distances between dorsal idiosomal setae and pores: $c 2: d 277-82, d 1: d 162-68, d 2: d 2$ 72-78, el:el 13-19, el:e2 68-80, el:h2 149-161, e2:h2 77-83, el:gl 39-43, gl:e2 33-44, h2:h2 32-33, h3:h3 26-31.

Epimerites I fused as in males. Epimerites IVa rudimentary. Epigynum large, bow-shaped, 36-38 long, 98-101 wide; setae $4 b$ encircled by epigynum. Apodemes of oviporus as wide roughly triangular sclerites. Setae $g$ set near ends of oviporal apodemes and epigynum tips, genital papillae slightly anterior to $g$. Setae $1 a$ short, not reaching the epigynum. All ventral setae short, $p s 2$ shaped as microsetae. Distances between ventral setae: $4 b: g$ 27-30, g:ps3 217-219, ps2:ps3 23-25, 4a:ps3 92-95.

Legs I and II shaped as in male. Legs III slightly slimmer than IV, with tarsal tips attaining the level of setae ps3. Ambulacra of legs IV not attaining the level of membranous opisthosomal tips. Tarsi III and IV with similar dorso-basal apophyses as in males. Setae $s R$ III narrowly lanceolate, 19-22 in length (Fig. 2B). Length of solenidia: $\sigma$ I 69-72, $\sigma$ II 46-56, $\sigma$ III 25-31, $\varphi$ I 89-96, $\varphi$ II 98-104, $\varphi$ III 61-64, $\varphi$ IV 35-37, $\omega 1$ I 27-28, c3 I 33-40, 1 I II 21-24.

Depository. Holotype and paratypes in the Department of Animal Morphology, AMU, Poznań, Poland.

DNA barcode. GenBank accession numbers for COI from 5 specimens: MH593806-MH593810 (COI). 
Etymology. The species is named after Dr. Andrei Vladimirovich Bochkov (1968-2018), a superb Russian zoologist, world leading specialist of parasitic mites of mammals, my collaborator and a dear friend (JD).

Differential diagnosis. The new species Calcealges bochkovi sp.n. is very close to C. gyroplax Gaud et Mouchet, 1957 described from Calyptocichla serinus (type host) and Phyllastrephus terrestris (Pycnonotidae). The comparative data for C. gyroplax are from the original description by Gaud and Mouchet (1957) and the redescription by Orwig (1968). Both sexes of these species have very similar general body appearance, in the shapes of the prodorsal and hysteronotal shields, and in the ventral coxosternal sclerotization. Males of both species have a similar structure of the genital apparatus. The males are also similar in having the spatuliform posterior part of opisthosoma with a pair of terminal lamellae, with 5-7 denticles each. Females of both species belong to a species group that have straight and parallel opisthosomal lobes with sharply pointed ends. The shapes and the dimensions of spermatheca and spermaducts in both species are identical.

The new species differs from $C$. gyroplax in the following features: in both sexes of $C$. bochkovi, prodorsal shields are smaller (122-127 $\times$ $147-157$ in males, $124-135 \times 161-167$ in females), with acute posterior corners and distinct transverse striation in posterior part; setae $s i$ are short (about 20-30), approximately half the distance between their bases; and setae $h 3$ are distinctly enlarged in the basal part. In both sexes of $C$. gyroplax, prodorsal shields are bigger $(137 \times 185$ in males, $157 \times$ 233 in females), with widely rounded posterior corners and without striation; setae $s i$ are longer (about 70), approximately as long as the distance between their bases; and setae $h 3$ are not enlarged in the basal part. In males of C. bochkovi, the body is smaller (397-409 × 191-216), and the medial part of the hysteronotum has fine transverse striation between setae $d 2$ and $e 1$. In males of C. gyroplax, the body is bigger $(440 \times 242)$ and the hysteronotal shield is uniformly dotted without striation. In females of $C$. bochkovi, the copulatory opening is situated almost at the level of setae $e l$, 100-104 from the free margin of the interlobar membrane; the ambulacra of legs IV do not reach the tips of opisthosomal lobes. In females of $C$. gyroplax, the copulatory opening is situated distinctly posterior to the level of setae $e 1$, about 62 from the free margin of interlobar membrane; legs IV with ambulacra extend slightly beyond the tips of opisthosomal lobes.

Remarks. Setae of segment E ( $e 1$ and $e 2)$ in most investigated females are set asymmetrically: in both setal pairs, their left and right setae do not occupy the same transverse level (Figs. 2A, 5A-E.). Other idiosomal setae, pores, and body parts are situated symmetrically. However, the current sample is too small to state if it is a developmental anomaly that happened in a single population vs. a specific characteristic of the entire species. The figure of a female Calcealges gyroplax, the closest relative of C. bochkovi, prepared by Orwig (1968), shows these setae set symmetrically, as in all other Calcealges species.

\section{ACKNOWLEDGEMENTS}

We are thankful to Mirka Dabert (Molecular Biology Techniques Laboratory, Faculty of Biology, AMU) for her effort in extracting DNA barcodes used in the present study. We thank Zak Pohlen and Callie Gesmundo (Wildlife Conservation Society, USA) for their help in capturing the birds for this study.

\section{REFERENCES}

Bishop, D.M. and Heath, A.C.G. 1998. Checklist of ectoparasites of birds in New Zealand. Surveillance, 25: 13-31.

Dabert, J., Ehrnsberger, R. and Dabert, M. 2008. Glaucalges tytonis sp. n. (Analgoidea: Xolalgidae) from the barn owl Tyto alba (Strigiformes: Tytonidae): compiling morphology with DNA barcode data for taxa descriptions in mites (Acari). Zootaxa, 1719: 41-52.

Gaud, J. 1952. Sarcoptides plumicoles des oiseaux de Madagascar. Mémoires de l'Institut scientifique de Madagascar, Séries A, 7: 81-107.

Gaud, J. 1962. Sarcoptiformes plumicoles (Analgesoidea) parasites d'oiseaux de l'ile Rennell. Natural History of Rennell Island, British Solomon Islands, 4: 31-51.

Gaud, J. 1968. Sarcoptiformes plumicoles (Analgoidea) parasites d'oiseaux de l'Ile Rennell. Natural History of Rennell Island, British Solomon Islands, 5: 121-151.

Gaud, J. and Atyeo, W.T. 1996. Feather mites of the World (Acarina, Astigmata): the supraspecific taxa. Annales du Musée Royal de l'Afrique Centrale, Sciences Zoologiques, 277, 1-193 (Pt. 1, text), 1-436 (Pt. 2, illustrations). 
Gaud, J. and Mouchet, J. 1957. Acariens plumicoles (Analgesoidea) des oiseaux du Cameroun I. - Proctophyllodidae. Annales de Parasitologie, 32: 491-546.

Gill, F. and Donsker, D. (Eds.). 2019. IOC World Bird List (v9.2). DOI: 10.14344/IOC.ML.9.2. Accessed 21 August 2019.

Hernandes, F.A. 2015. Two new feather mites of the genus Calcealges Gaud, 1952 (Acari: Trouessartiidae) from antbirds (Passeriformes: Thamnophilidae) in Brazil. Systematic Parasitology, 91: 241-252.

McClure, H.E. and Ratanaworabhan, N. 1973. Some ectoparasites of the birds of Asia. Jintana Printing Ltd, Bangkok. 219 pp.

Mironov, S.V. 1987. Morphological adaptations of feather mites to different types of plumage and to skin of birds. Parasitologicheskij sbornik, 34: 114-132.

Mironov, S.V., Dabert, J. and Dabert, M. 2012. A new feather mite species of the genus Proctophyllodes Robin, 1877 (Astigmata: Proctophyllodidae) from the Long-tailed Tit Aegithalos caudatus (Passeriformes: Aegithalidae) - morphological description with DNA barcode data. Zootaxa, 3253: 54-61.

Mironov, S.V. and Galloway, T. D. 2019. Feather mites of the genus Trouessartia Canestrini (Acari- formes: Trouessartiidae) from swallows (Passeriformes: Hirundinidae) in Canada. Zootaxa, 4568: 1-39.

Mironov, S.V. and Palma, R. 2016. A new feather mite of the genus Trouessartia Canestrini 1899 (Acariformes: Trouessartiidae) from the Seychelles magpie-robin, Copsychus sechellarum (Passeriformes: Muscicapidae). Acta Parasitologica, 61: 628-635.

Norton, R.A. 1998. Morphological evidence for the evolutionary origin of Astigmata (Acari: Acariformes). Experimental and Applied Acarology, 22: 559-594.

Orwig, K.R. 1968. The genera and species of the feather mite subfamily Trouessartinae except Trouessartia (Acarina: Proctophyllodidae). Bulletin of the University of Nebrasca State Museum, 8: 1-185.

Santana, F.J. 1976. A review of the genus Trouessartia (Analgoidea: Alloptidae). Journal of Medical Entomology, Supplement 1: 1-128.

Trouessart, E.L. and Neumann, G., 1888. Diagnoses d'especes nouvelles de Sarcoptides plumicoles (Analgesinae). Bulletin Scientifique de la France et de la Belgique, 19: 325-380. 
J. Dabert and M. Bąkowski

\begin{tabular}{|c|c|c|c|c|c|c|c|c|c|c|c|c|c|c|}
\hline 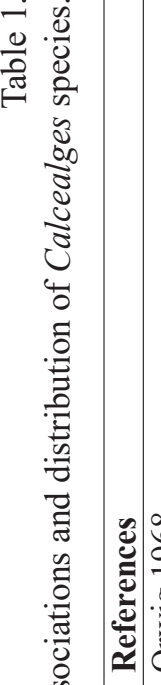 & 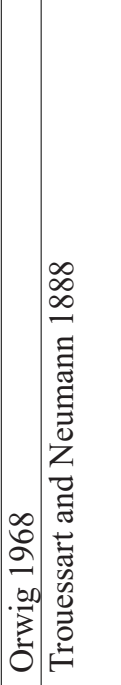 & 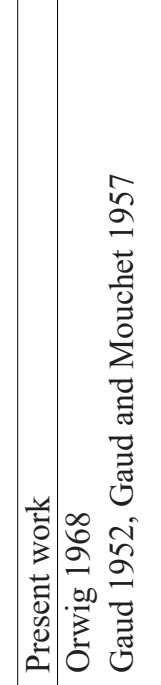 & 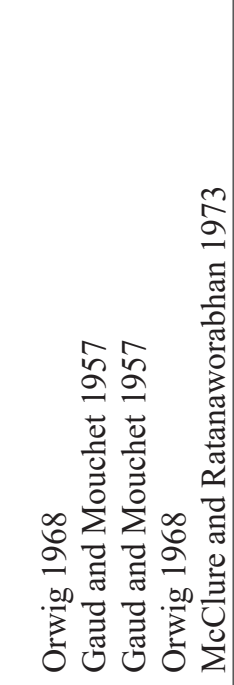 & 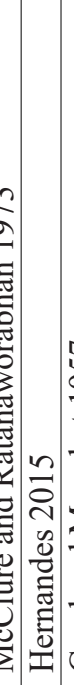 & 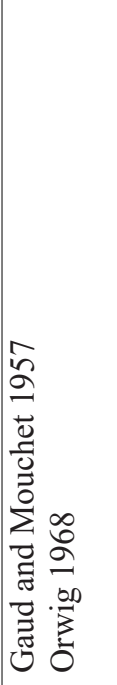 & 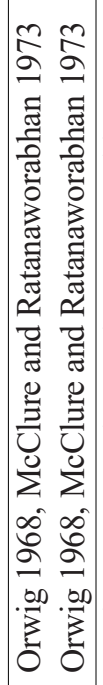 & 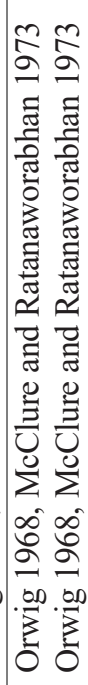 & $\mid \begin{array}{c}\infty \\
0 \\
2 \\
0 \\
.00 \\
3 \\
0 \\
0\end{array}$ & 尽 & 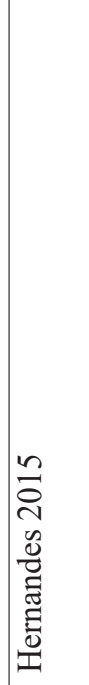 & 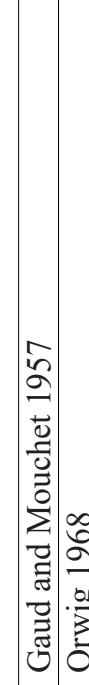 & 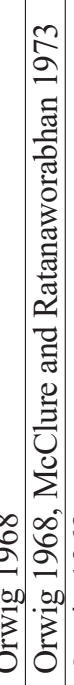 & 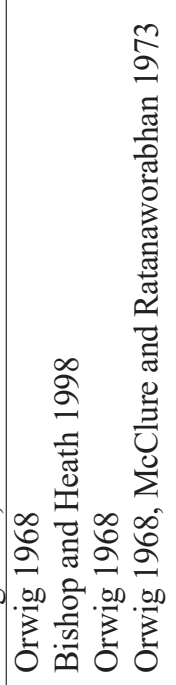 & 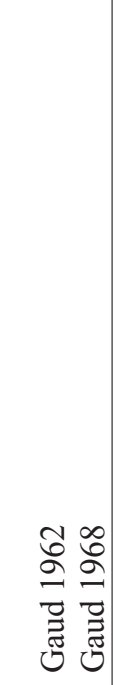 \\
\hline : & 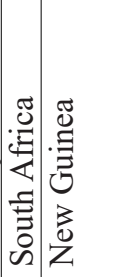 & 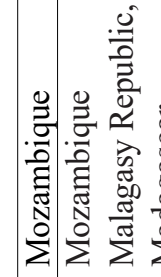 & 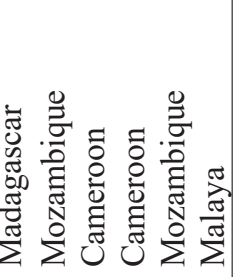 & 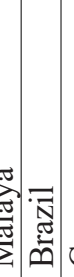 & 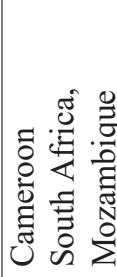 & 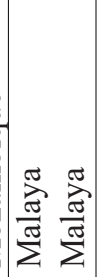 & 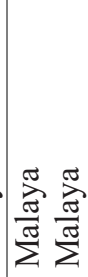 & & 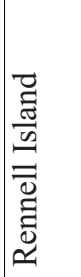 & $\begin{array}{l}\overline{\bar{N}} \\
\overline{\mathscr{D}} \\
\end{array}$ & 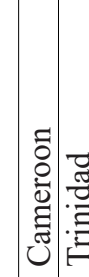 & 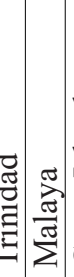 & 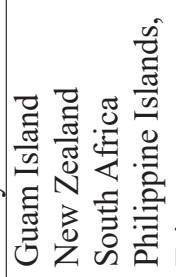 & 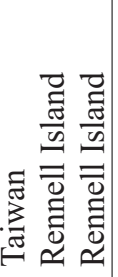 \\
\hline : & 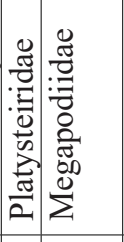 & 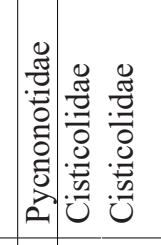 & 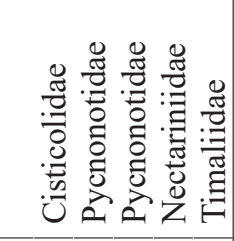 & 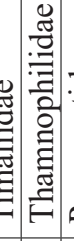 & 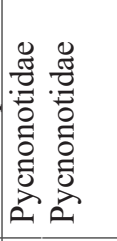 & 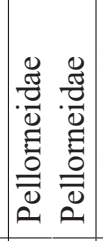 & 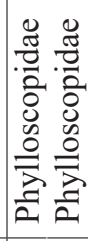 & & 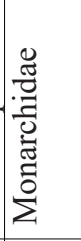 & 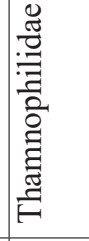 & 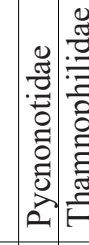 & 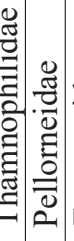 & 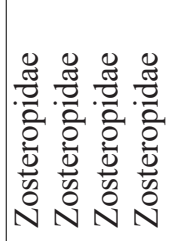 & 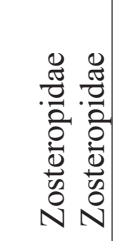 \\
\hline 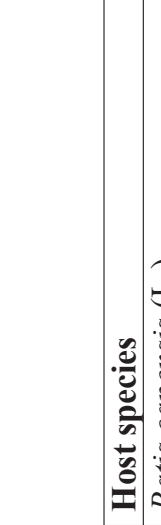 & 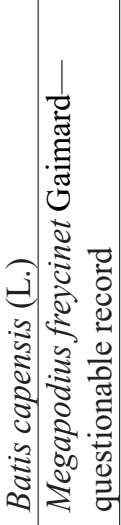 & 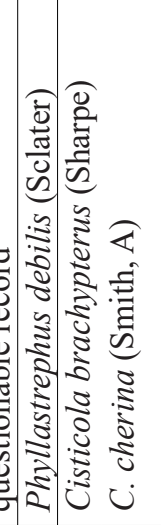 & 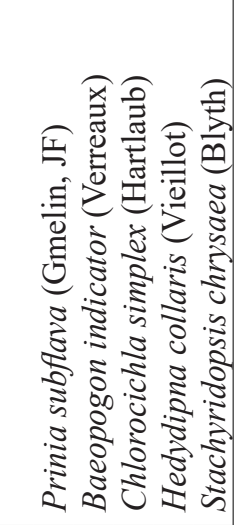 & 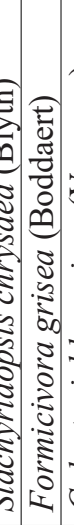 & 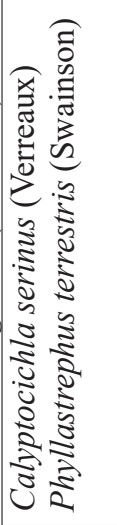 & 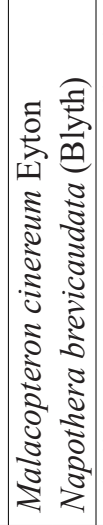 & 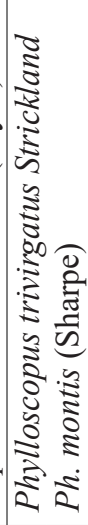 & & 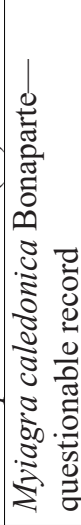 & 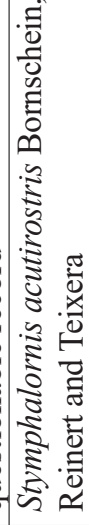 & 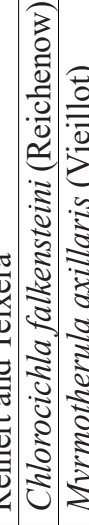 & 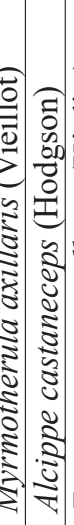 & 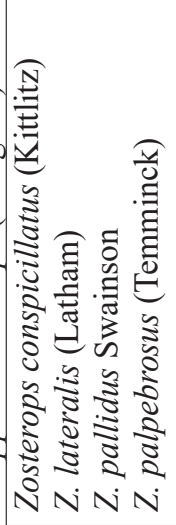 & 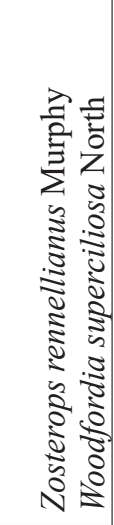 \\
\hline 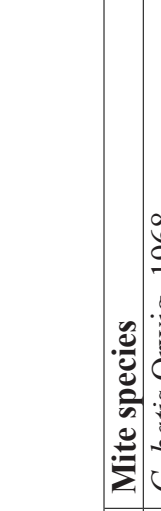 & 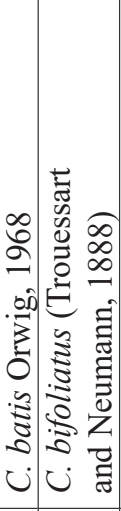 & 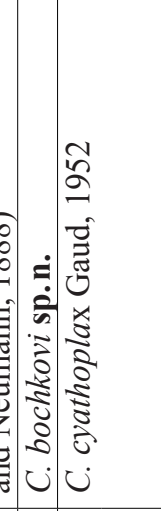 & & 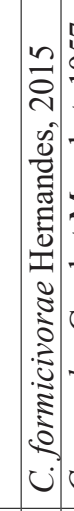 & 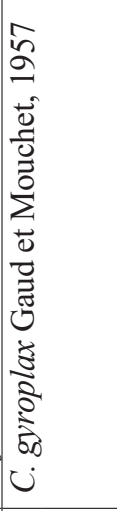 & 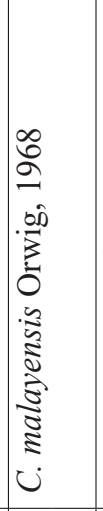 & 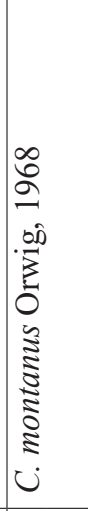 & 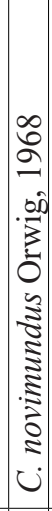 & 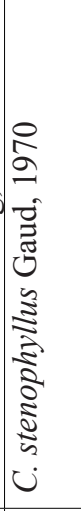 & 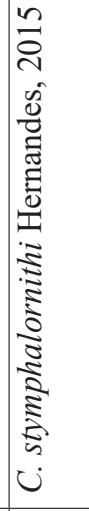 & 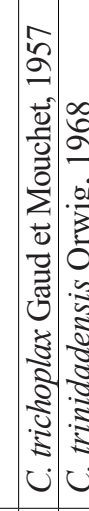 & 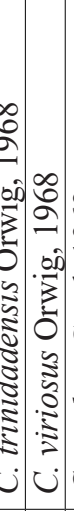 & 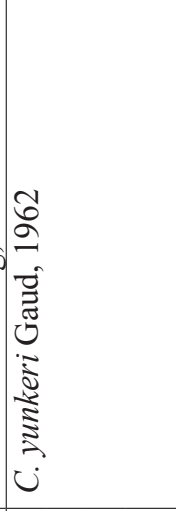 & \\
\hline \# & $-\pi$ & $m+$ & & $n$ & 6 & 1 & $\infty$ & & & - & & $\therefore=$ & - & \\
\hline
\end{tabular}

